\title{
Comparative effectiveness study of vinpocetine vs. nimodipine on functional recovery in patients of head injury
}

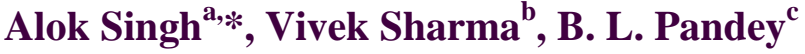

\begin{abstract}
a Department of Pharmacology, G.R. Medical College, Gwalior474001, Madhya Pradesh, India ${ }^{\mathrm{b}}$ Department of Neurosurgery, Institute of Medical Sciences, Banaras Hindu University, Varanasi-221005, Uttar Pradesh, India

${ }^{\mathrm{c}}$ Department of Pharmacology, Institute of Medical Sciences, Banaras Hindu University, Varanasi-221005, Uttar Pradesh, India
\end{abstract}

Received: 12 December 2012 Accepted: 21 December 2012

\author{
*Correspondence to: \\ Dr. Alok Singh \\ Email: \\ draloksingh410@gmail.com
}

\begin{abstract}
Background: Head injuries are increasing cause of overall disability which needs aggressive researches on neuroprotective agents to prevent or rectify the sequelae of brain damage. The outcomes on functional recovery following add on therapies either nimodipine or vinpocetine was done to compare merits of either therapies.

Methods: 90 head injury cases admitted to S.S. hospital were divided into standard treatment group given neither vinpocetine nor nimodipine \& other two groups given either nimodipine or vinpocetine dependent entirely on clinician's discretion. The patients data on initial severity on GCS scale and functional recovery on Barthel Index, head injury watch scale, Disability rating score were collected at discharge $\&$ at one month follow up thereafter to compare the recovery profiles.

Results: Vinpocetine treatment proved superior to nimodipine or standard treatment on examining the outcomes. Significance of time since injury was emphasized for improved outcome to nimodipine but not so necessary for vinpocetine.

Conclusions: Nimodipine delayed administration had no consequence while vinpocetine is useful treatment at any stage to enhance functional recovery in cases of head injury.
\end{abstract}

Keywords: Vinpocetine, Nimodipine, Head injury

\section{INTRODUCTION}

Remodeling of central nervous system pathways, particularly in the cortex but also in other parts of brain and spinal cord, are of compelling interest in clinical recovery of neural function. Traumatic brain injury (TBI) is known to cause both necrotic and apoptotic death of neurons and both processes may be pharmacologically manipulated. ${ }^{1}$ Such knowledge has led to evaluation of numerous pharmacological strategies like Calcium channel blockers, Corticosteroids and other antioxidants, glutamate receptor antagonists, Magnesium administration, various anti-inflammatory and immune modulating treatments. ${ }^{2}$ Patients with severe head injuries differ in regard to underlying mechanisms of secondary injury, which includes varying degrees of hypoxia, ischemia, contusion, diffuse axonal injury, edema and the presence of associated hematoma. ${ }^{3}$ Although patient may show excellent recovery by various neurological scores, he may still suffer for weeks for month of misery, worry forgetfulness and defect of concentration, imbalance and vertigo. Drugs may be broadly categorized as those which limit acute ischemia and death of nerve cells. Others may interfere with various components of ischemic cascade for delayed mechanisms of neuronal death, such as glutamate induced excitotoxicity, free radical mediated injury or inflammatory mechanism.

Vinpocetine (ethyl apovincaminate) is a semisynthetic derivative alkaloid of vincamine, an extract from the periwinkle plant Vinca minor. It has shown different pharmacological actions thorough variety of mechanisms. It has a well documented effect on cerebral glucose metabolism and blood flow. ${ }^{4-6}$ It also has well described vascular and rheological effects, including decrease in cerebral vascular resistance as well as positive changes on erythrocyte deformability and platelet aggregability. ${ }^{7-9}$ However in spite of a body of accumulated clinical evidence on the neuroprotective effects and therapeutic usefulness of vinpocetine, the drug's main pharmacological and physiological actions are still not understood in detail. 
Nimodipine is a dihydropyridine calcium channel antagonist implicated to have a cerebro-protective effect. It has receptors on both neurons and cerebral vessels and is reported to protect neurons, stabilize their function, promote cerebral blood flow, and increase tolerance to ischemia by reducing calcium entry into nerve and smooth muscle cells. Nimodipine, L type Calcium channel blocking agent, has potent vasodilatory effect on cerebral vessels and increases cerebral blood flow. The neuroprotective effect of nimodipine is still not completely clear but, might be related to vasodilating, and calcium channel blocking.

The study however intended to detect trends in recovery over short one month treatment period of these add on therapies after discharge of patients from hospital. This study while examining the impact of add on therapies on recovery parameters simultaneously tries to comprehend diverse limitations host by peculiarities of patient profile and profile of drug usage.

\section{METHODS}

The patients presenting with head injury at the neurosurgery speciality of Sir Sunderlal hospital Institute of Medical Sciences Banaras Hindu University were subject of the study. They ranged in 18-65 years age and of either sex complete clinical history neurological examination and computer tomographic confirmation of brain trauma was undertaken. Patient revealing major renal, hepatic, pulmonary or cardiac derangement through clinical examination were excluded. Institutional Ethics committee approved the study. Purpose of study was explained and informed consent was obtained from patient attendant with assurance of not revealing identity. The therapies examined are in regular prescription at discretion of the clinician in various head injury cases. Nimodipine or vinpocetine are employed purely as adjunct in management of head injury cases. Vinpocetine at discharge was prescribed at $5 \mathrm{mg}$ thrice daily and nimodipine $60 \mathrm{mg} 4$ hourly respectively for 30 and 21 days. The drugs administered during hospital stay and after discharge were also recorded. Daily assessment of all the vital parameters \& other neurological parameters were also done during their hospital stay. Any adverse effect of drug was also documented.

The Barthel index, Disability Rating Scale and Head Injury Watch Scale were used to assess the functional status of the patients at discharge and at one month of follow-up. Moods median test was adopted for comparing outcomes on individual parameters of recovery rating scales in the different studied groups. Mann-Whitney U test analysis was adopted for testing significance of differences in the examined scores in studied groups. Comparison of each add on therapy group i.e.
Vinpocetine and Nimodipine was independently performed with the standard treatment group and respective $p$ values of such comparison are tabulated against the add-on therapy group.

\section{RESULTS}

This study was conducted between January 2010 and April 2011 with 90 cases i.e. 30 and 20 cases of Vinpocetine and Nimodipine add on therapy and rest of 40 cases belonging to the standard treatment group.

Table 1 presents clinical characteristics of better and poor gainers in Barthel Index after one month treatment since discharge with different regimens. Patients above 40 years of age in all the treatment group more often achieved below median improvement. Male patients more often exhibited above median recovery in the standard therapy group and below median recovery in either add on therapy groups. Female patients exhibited reverse pattern with more frequent above median recoveries in add on therapy groups and below median recovery in standard treatment group. Cases undergoing neurosurgical treatment following head injury had below median recovery more often in standard and nimodipine treated groups, but more frequent above median recovery in vinpocetine treated group.

Mean GCS scores at admission were comparable between gainers with above and below median recovery in all the studied groups. Greater delay in initiation of hospital care since incurring head injury was consistently associated with below median gain in all the groups. The institution of add on nimodipine treatment with marginal delay resulted in chances of less median gain in recovery but not so in case of vinpocetine treatment, where delayed institution was somewhat greater above those gaining above median. Mannitol administration was associated with more frequent above median gain in recovery in standard treatment group. In the either groups of add on therapies patients receiving mannitol more often exhibited below median gains in recovery. Patients sustaining head injuries on left side more often had below median gains as compared to those on right side injury in all the studied groups.

Patients clinically judged to have diffuse brain injury more frequently exhibited below median gain in recovery with standard treatment or add on nimodipine treatment. Such detrimental consequences were not seen in vinpocetine treated group, although number of patients was much smaller. Road traffic accident was found to be predominant cause of head injury in all the groups. Absence of skull fracture was associated with better recovery, no direct relation exists between type of injury and recovery. 
Table 1: Characteristics of cases yielding better \& poorer outcome in Barthel Index in study group.

\begin{tabular}{|c|c|c|c|c|c|c|}
\hline \multirow[b]{2}{*}{ Characteristics } & \multicolumn{2}{|l|}{ Standard } & \multicolumn{2}{|l|}{ Nimodipine } & \multicolumn{2}{|l|}{ Vinpocetine } \\
\hline & $\begin{array}{l}\text { Higher } \\
\text { Improvement } \\
\text { (>median) }\end{array}$ & $\begin{array}{l}\text { Less } \\
\text { Improvement } \\
\text { ( } \leq \text { Median) }\end{array}$ & $\begin{array}{l}\text { Higher } \\
\text { Improvement } \\
\text { (>median) }\end{array}$ & $\begin{array}{l}\text { Less } \\
\text { Improvement } \\
\text { ( } \leq \text { Median) }\end{array}$ & $\begin{array}{l}\text { Higher } \\
\text { Improvement } \\
\text { (>median) }\end{array}$ & $\begin{array}{l}\text { Less } \\
\text { Improvement } \\
\text { ( } \leq \text { Median) }\end{array}$ \\
\hline No. of total cases & 20 & 20 & 8 & 12 & 14 & 16 \\
\hline No. of cases (>40 years) & 4 & 10 & 4 & 10 & 4 & 8 \\
\hline \multicolumn{7}{|l|}{ Sex } \\
\hline Male & 14 & 10 & 6 & 10 & 8 & 10 \\
\hline Female & 6 & 10 & 2 & 2 & 6 & 6 \\
\hline No. of cases with Surgery & 12 & 12 & 8 & 12 & 8 & 2 \\
\hline $\begin{array}{l}\text { Initial Glasgow coma } \\
\text { score(mean) }\end{array}$ & 10.8 & 10.2 & 8 & 7.6 & 12 & 11.1 \\
\hline Time since injury to initiate & \multirow[b]{2}{*}{$6 \mathrm{hrs}}$. & \multirow[b]{2}{*}{$8.5 \mathrm{hrs}$. } & & & & \\
\hline \begin{tabular}{|l} 
General Treatment \\
Specific ad on drug treatment \\
\end{tabular} & & & $\begin{array}{l}6.5 \text { hrs. } \\
6.2 \text { days } \\
\end{array}$ & $\begin{array}{l}10 \text { hrs. } \\
8.8 \text { days } \\
\end{array}$ & $\begin{array}{l}6.2 \text { hrs } \\
7.5 \text { days } \\
\end{array}$ & $\begin{array}{l}8.5 \text { hrs. } \\
6 \text { days } \\
\end{array}$ \\
\hline Administration of Mannitol & 10 & 6 & 8 & 12 & 8 & 14 \\
\hline \multicolumn{7}{|l|}{ Involvement of brain } \\
\hline Right Side & 10 & 8 & 4 & 6 & 4 & 2 \\
\hline Left Side & 4 & 10 & 4 & 6 & 6 & 12 \\
\hline $\begin{array}{l}\text { No. of cases with diffuse } \\
\text { injury }\end{array}$ & 4 & 5 & 4 & 10 & 6 & 4 \\
\hline \multicolumn{7}{|l|}{ Cause of Injury } \\
\hline Road Traffic Accident & 12 & 10 & 6 & 6 & 10 & 10 \\
\hline Fall from Height & 6 & 6 & 0 & 4 & 4 & 2 \\
\hline Physical Assault & 2 & 4 & 2 & 2 & 0 & 4 \\
\hline Skull \# & 6 & 8 & 4 & 8 & 4 & 6 \\
\hline \multicolumn{7}{|l|}{ CT scan } \\
\hline Contusion & 8 & 4 & 0 & 0 & 4 & 12 \\
\hline Extradural hematoma & 6 & 14 & 0 & 0 & 6 & 2 \\
\hline \begin{tabular}{|l|} 
Intradural hematoma \\
\end{tabular} & 0 & 0 & 4 & 12 & 0 & 0 \\
\hline Diffuse Axonal Injury & 6 & 2 & 0 & 0 & 4 & 2 \\
\hline
\end{tabular}

Table 2: Outcome at one month after injury.

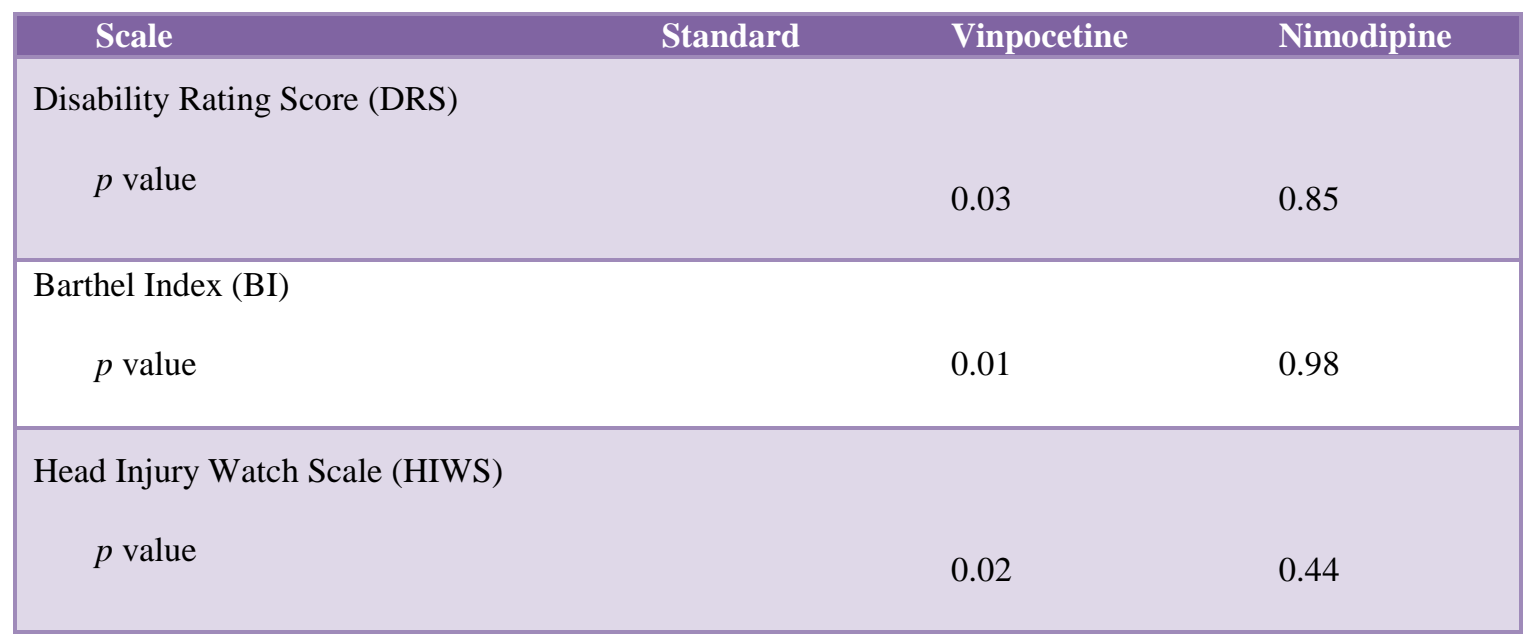


Table 3: Functional assessment after one month by Barthel Index.

\begin{tabular}{|c|c|c|c|}
\hline Parameter & $\begin{array}{l}\text { Standard } \\
\text { No. of cases above the pooled } \\
\text { median / No. of cases equal } \\
\text { or below pooled median }\end{array}$ & $\begin{array}{l}\text { Vinpocetine } \\
\text { No. of cases above the } \\
\text { pooled median / No. of } \\
\text { cases equal or below } \\
\text { pooled median }\end{array}$ & $\begin{array}{l}\text { Nimodipine } \\
\text { No. of cases above the } \\
\text { pooled median / No. of } \\
\text { cases equal or below } \\
\text { pooled median }\end{array}$ \\
\hline Feeding & $16 / 24$ & $\begin{array}{l}20 / 10 \\
p \text { value- } 0.20-0.10\end{array}$ & $\begin{array}{l}8 / 12 \\
p \text { value- } 0.70\end{array}$ \\
\hline Bathing & $8 / 32$ & $\begin{array}{l}18 / 12 \\
p \text { value- } 0.05-0.02\end{array}$ & $\begin{array}{l}6 / 14 \\
p \text { value- } 0.90\end{array}$ \\
\hline Grooming & $8 / 32$ & $\begin{array}{l}20 / 10 \\
p \text { value- } 0.02-0.01\end{array}$ & $\begin{array}{l}6 / 14 \\
p \text { value- } 0.90\end{array}$ \\
\hline Dressing & $10 / 30$ & $\begin{array}{l}18 / 12 \\
P \text { value- } 0.05-0.02\end{array}$ & $\begin{array}{l}6 / 14 \\
p \text { value- } 0.80-0.70\end{array}$ \\
\hline Bowels & $14 / 26$ & $\begin{array}{l}12 / 18 \\
p \text { value- } 0.90-0.80\end{array}$ & $\begin{array}{l}10 / 10 \\
p \text { value- } 0.80\end{array}$ \\
\hline Bladder & $2 / 38$ & $\begin{array}{l}10 / 20 \\
p \text { value- } 0.10-0.05\end{array}$ & $\begin{array}{l}2 / 18 \\
p \text { value- } 0.90\end{array}$ \\
\hline Toilet use & $10 / 30$ & $\begin{array}{l}24 / 6 \\
p \text { value- } 0.01\end{array}$ & $\begin{array}{l}8 / 12 \\
p \text { value- } 0.70-0.50\end{array}$ \\
\hline $\begin{array}{l}\text { Transfer } \\
\text { (bed to } \\
\text { chair and } \\
\text { back) }\end{array}$ & $4 / 36$ & $\begin{array}{l}18 / 12 \\
p \text { value- } 0.05-0.02\end{array}$ & $\begin{array}{l}12 / 8 \\
p \text { value- } 0.05-0.02\end{array}$ \\
\hline $\begin{array}{l}\text { Mobility } \\
\text { on level } \\
\text { surface }\end{array}$ & $4 / 36$ & $\begin{array}{l}18 / 12 \\
p \text { value- } 0.05-0.02\end{array}$ & $\begin{array}{l}12 / 8 \\
p \text { value- } 0.05-0.02\end{array}$ \\
\hline Stairs & $10 / 30$ & $\begin{array}{l}20 / 10 \\
p \text { value- } 0.02-0.01\end{array}$ & $\begin{array}{l}14 / 6 \\
p \text { value- } 0.05\end{array}$ \\
\hline
\end{tabular}

Table 2 provides profile of recovery in terms of gain over disability scores at discharge, after one month treatment in different groups. This shows patients on vinpocetine add on therapy recovered better with significantly more gain assessed on DRS, BI and HIWS. Nimodipine treated group exhibited no difference in recovery from the standard group. When gains are measured as percent improvement over the score at discharge similar outcome is manifest with Vinpocetine group fostering better recovery while no difference occurred with Nimodipine add on therapy.

Table 3 presents recovery profiles on various parameters of BI following one month treatment after discharge in different groups. Vinpocetine treatment significantly improved parameters of self care viz. bathing, grooming, dressing while feeding was only marginally improved. Bladder control was also marginally improved but not the bowel control, however there was significant improvement in patients cooperation toward toilet use. Nimodipine didn't offer any benefits in these regards when compared to the standard treatment group. Assisted motor activities viz. transfer (from bed to chair and back), mobility on level surface and negotiation of stairs was significantly improved both by Nimodipine and vinpocetine add on treatments over that seen in standard treatment group.

In table 4 neither vinpocetine nor nimodipine add on therapy significantly improved items measuring arousability, awareness and responsivity of patients compared to that in standard treatment group. The parameters testing cognitive ability for self care activities under DRS exhibit significant improvement with Vinpocetine add on therapy but not with nimodipine add on therapy in comparison to standard treatment group. Dependence on others and level of functioning examined under DRS shows significant beneficial outcome by Vinpocetine therapy when compared to outcomes in standard treatment group. Table 5 presents recovery profiles on various parameters of HIWS after one month treatment following discharge in 3 studied group. The parameters relating consciousness and perception were not significantly better improved over the standard treatment group either by vinpocetine or by nimodipine add-on treatment. 
Table 4: Functional assessment after one month by Disability Rating Scale.

\begin{tabular}{|c|c|c|c|}
\hline Parameter & $\begin{array}{l}\text { Standard } \\
\text { No. of cases above the pooled } \\
\text { median / No. of cases equal } \\
\text { or below pooled median }\end{array}$ & $\begin{array}{l}\text { Vinpocetine } \\
\text { No. of cases above the } \\
\text { pooled median / No. of } \\
\text { cases equal or below } \\
\text { pooled median }\end{array}$ & $\begin{array}{l}\text { Nimodipine } \\
\text { No. of cases above the } \\
\text { pooled median / No. of } \\
\text { cases equal or below } \\
\text { pooled median }\end{array}$ \\
\hline Eye opening & $6 / 34$ & $\begin{array}{l}6 / 24 \\
p \text { value- } 0.95\end{array}$ & $\begin{array}{l}8 / 12 \\
p \text { value- } 0.30-0.20\end{array}$ \\
\hline $\begin{array}{l}\text { Communication } \\
\text { ability }\end{array}$ & $18 / 22$ & $\begin{array}{l}14 / 16 \\
p \text { value- } 0.90\end{array}$ & $\begin{array}{l}10 / 10 \\
p \text { value- } 0.90-0.80\end{array}$ \\
\hline Motor response & $8 / 32$ & $\begin{array}{l}12 / 18 \\
p \text { value- } 0.90-0.80\end{array}$ & $\begin{array}{l}8 / 12 \\
p \text { value- } 0.50-0.30\end{array}$ \\
\hline Feeding & $0 / 40$ & $\begin{array}{l}4 / 26 \\
p \text { value- } 0.5-0.3\end{array}$ & $\begin{array}{l}4 / 16 \\
p \text { value- } 0.20-0.10\end{array}$ \\
\hline Toileting & $0 / 40$ & $\begin{array}{l}10 / 20 \\
p \text { value- } 0.02\end{array}$ & $\begin{array}{l}2 / 18 \\
p \text { value- } 0.80-0.70\end{array}$ \\
\hline Grooming & $12 / 28$ & $\begin{array}{l}22 / 8 \\
p \text { value- } 0.05-0.02\end{array}$ & $\begin{array}{l}6 / 14 \\
p \text { value- } 0.70-0.50\end{array}$ \\
\hline $\begin{array}{l}\text { Level of } \\
\text { Functioning }\end{array}$ & $10 / 30$ & $\begin{array}{l}18 / 12 \\
p \text { value- } 0.05-0.02\end{array}$ & $\begin{array}{l}8 / 12 \\
p \text { value- } 0.70-0.50\end{array}$ \\
\hline Employability & $0 / 40$ & $\begin{array}{l}2 / 28 \\
p \text { value- } 0.99\end{array}$ & $0 / 20$ \\
\hline
\end{tabular}

Pain perception and non-verbal response was significantly better in group receiving Vinpocetine add on therapy as compared to standard group. Nimodipine also benefitted but difference with standard treatment group was not statistically significant. Nimodipine add on treatment as well as vinpocetine add on treatment significantly improved withdrawal response to pain stimulus. Nimodipine effect was even better than vinpocetine. Autonomic pupillary reflex was not significantly changed either by vinpocetine or by nimodipine as compared standard treatment group.

Table 5: Functional assessment after one month by Head Injury Watch Scale.

\begin{tabular}{|llll|}
\hline Parameter & $\begin{array}{l}\text { Standard } \\
\text { No. of cases above the pooled } \\
\text { median / No. of cases equal } \\
\text { or below pooled median }\end{array}$ & $\begin{array}{l}\text { Vinpocetine } \\
\text { No. of cases above the } \\
\text { pooled median / No. of } \\
\text { cases equal or below pooled } \\
\text { median }\end{array}$ & $\begin{array}{l}\text { Nimodipine } \\
\text { No. of cases above the } \\
\text { pooled median / No. of } \\
\text { cases equal or below } \\
\text { pooled median }\end{array}$ \\
\hline $\begin{array}{l}\text { Response to } \\
\text { verbal } \\
\text { commands }\end{array}$ & $14 / 26$ & $\begin{array}{l}20 / 10 \\
\text { value-0.20-0.10 }\end{array}$ & $\begin{array}{l}10 / 10 \\
p \text { value-0.30 }\end{array}$ \\
\hline $\begin{array}{l}\text { Stimulus to } \\
\text { awaken }\end{array}$ & $10 / 30$ & $14 / 16$ & $8 / 12$ \\
\hline $\begin{array}{l}\text { Quality of } \\
\text { consciousness }\end{array}$ & $18 / 22$ & $\begin{array}{l}\text { value- } 0.20-0.10 \\
p \text { value- } 0.70-0.50\end{array}$ \\
\hline $\begin{array}{l}\text { Non verbal } \\
\text { reaction to } \\
\text { pain }\end{array}$ & $2 / 38$ & $p$ value- 0.99 & $10 / 10$ \\
\hline $\begin{array}{l}\text { Ability to } \\
\text { move each } \\
\text { extremity }\end{array}$ & $0 / 40$ & $12 / 18$ & $6 / 14$ \\
\hline Pupils & $0 / 40$ & $p$ value- $0.05-0.02$ & $p$ value-0.20-0.10 \\
\hline
\end{tabular}




\section{DISCUSSION}

Management of head injury focuses on preventing, detecting and correcting the secondary brain injury after trauma. Mental sequelae of head injury most frequently relate to diffuse brain damage as axon lesions associated with secondary hypoxic damage have very wide distribution. Consequences to these performance tests are more impaired as they depend upon wide range and integration of cerebral activities. The derangement also reflects on aspects of higher functions like motivation and attention, speed of performance and perseverance of organizing ability for complex tasks for different periods. The consequences of diffuse injury resemble mental deterioration with aging so the victim may perform normally in routine familiar context but poorly in new situation and demands. Defective psychological traits of persons before trauma may impair recovery of interactive social functions and requisite cognition toward performance. Cognition and memory deficits and personality changes hinder social reintegration and new stresses environment after discharge may evoke reactive agitation, depression and other psychiatric symptoms.

Glasgow Coma Scale (GCS) is employed to grade the severity of traumatic brain injury (TBI) at time of admission of cases. The scale primarily attempts to classify level of consciousness in patients. It is more of predictive test for future neurological status.

The Disability Rating Score (DRS) attempts to quantitatively assess rehabilitative progress of head injured patients, through successive stages of awareness and functioning. This scale was found significant to relate electro-physiologic indicators of brain functions. ${ }^{10}$ It provides quick global description of patient condition which facilitate understanding and communication. The scores are indicative of cognitive functioning. The head injury watch scale provides a method to quantitate rate of recovery in head injury. Ability of patients who respond to commands by motor movement may be taken as reliable method to assess consciousness. The scale may allow monitoring neurological status till patient achieves self care.

The Barthel Index (BI) is an assessment of patient level of independence. Barthel Index is a reliable measure of functional independence inclusive of recovery in motor function and balance, besides the motor recovery and balance BI score indirectly suggest also the Quality of Life. Cases with severe damage of brain may not benefit enough to show up the same in short term evaluation, and in too little brain damage the spontaneous recovery may eclipse detection of drug induced benefits. There was significant greater impairment in GCS score of patients prescribed nimodipine therapy which reflects the belief of clinicians in the drug as preferred agent when need for additive neuroprotection is perceived. Nevertheless, the biased inclusion of more severe cases of neurotrauma should be adequately discounted for while inferring the neuroprotective outcome, especially in contrast to vinpocetine. Both Vinpocetine and Nimodipine therapies were instituted around 7-10 days following injury.

Following one month treatment since discharge only the vinpocetine add on therapy group yielded significant improvement in disability measured by the 3 scales employed. Nimodipine add on therapy resulted in only minor benefit on single scale the BI. Part of the outcome may relate to significantly lower initial GCS scores in the nimodipine group compared to vinpocetine or the standard group.

Among patient characteristic aging is worthwhile issue to consider for possible impact on observed outcomes. Aging shares virtually all the mechanisms suggested for traumatic brain damage and should be additive to magnitude of pathology. 7 out of 20 cases in standard regimen cases; 6 out of 15 cases in vinpocetine and 7 out of 10 cases in nimodipine were above the common median age of 40 years. Although this doesn't statistically differ, higher proportion of aged individuals in nimodipine group is likely to be associated with less outcomes of nimodipine. Females are reported to withstand head injury better than male and cognitive recovery is also relatively faster in them. ${ }^{11}$

Again nimodipine group excess of males that may reflect negatively on therapeutic outcomes on account of differential sexual influence. Impact of injury on left side of head is reported to result in longer period of unconsciousness and recovery. ${ }^{12}$ Isolated left and right injuries in the groups were standard $7 / 9+4$ bilateral; vinpocetine $9 / 3+3$ bilateral and nimodipine $5 / 5 \&$ no bilateral. In this regard nimodipine group may be better placed for recovery than the other two. Among the confounding drug effects, mannitol needs to be considered whenever used during hospital stay as it may have neuroprotective effect of itself by fostering cerebral perfusion and scavenging hydroxyl radicals. While mannitol benefits stand apart the indication reflects instance of brain edema and diffuse injury. It is difficult therefore to predict the influence of mannitol treatment on outcomes.

Nimodipine is primarily a calcium channel blocker with high selectivity for brain. Its effects relate to twin consequences of selective vasodilatation in brain13; and blockade of injurious calcium in neural cells subjected to ischemic injury following head trauma. The ischemia induced membrane dysfunction provokes calcium ion influx which activate phospholipases resulting in release of arachidonate and cascading downstream products which disturb essential energy supply necessary for vital neural functions. ${ }^{14}$ Nimodipine has no cognitive potential to boost neuro-chemical events toward recovery. ${ }^{15}$ Nimodipine is clearly an agent that impairs learning function. ${ }^{16}$ Nimodipine however can prevent ischemic damage to cognitive ability to some extent. ${ }^{17}$ Some betterment of spatial working memory is brought about by nimodipine through elevation of Acetylcholine release in brain in rats. ${ }^{18}$ 
Vinpocetine shares vasodilatory potential of nimodipine and is also having calcium channel antagonist potential and is also strong antioxidant. Vinpocetine however, primarily a phosphodiesterase-1 (PDE1) inhibitor. It raises c-AMP resource of cell including neurons and checks the crucial energy failure in state of ischemia. Boosted c-AMP and c-GMP levels contribute to vasorelaxation. Prominent additional effects are decrease in blood viscosity and increase in erythrocyte flexibility; and the extraction of oxygen from hemoglobin by nerve cells is simultaneously promoted and glucose utilization is facilitated. Being effective sodium channel antagonist ${ }^{19}$ with calcium channel blocking ${ }^{20}$ property vinpocetine is effective protection against excite-toxic damage by NMDA and calcium influx. The indirect anti oxidative potential foster defence against free radical injury during ischemia- reperfusion. The drug has significant inhibitory effect on NF-kB translocation which makes it potent inhibitor of pro-inflammatory cytokine release. ${ }^{21}$ This enables vinpocetine to protect against the long term inflammation damage by injury activated glial tissue. The peripheral smooth muscle relaxant effect of vinpocetine particularly suits minimization of neurogenic disturbances in bladder and bowel control. ${ }^{22}$ Its PDE1 inhibitory activity is of increasing significance with emerging insights into purinergic receptors in neuronal differentiation and plasticity as well as neuroprotection. ${ }^{23}$ Vinpocetine also interacts with neurotransmitter systems like raising Noradrenaline turnover ${ }^{24}$ and increase in Acetylcholine ${ }^{25}$ release and 5-HT level ${ }^{26}$ and Dopamine and DOPAC ${ }^{27}$ level in brain. Thus, there are multiple mechanisms for cognition enhancement by vinpocetine. The drug has much less propensity to induce excess vasodilatation as compared to nimodipine which may increase risk of Hypothalamic- Pituitary- Adrenal axis dysfunction and psychosomatic derangements seen as Post Traumatic Stress Disorder. ${ }^{28}$ Overall impression from the study indicates greater belief of clinicians in neuroprotective credentials of Nimodipine which may be prescribed in rather serious cases but too late to be of any use. Vinpocetine emerges as clearly relevant rejuvenative drug for damaged brain at any stage. Its benefit ought to be examined. The present study reveals benefits essentially on the recovery process, however establishment of its role in effective check on initial ischemic events may make it the preferred options as neuroprotective for cases of head injury.

\section{CONCLUSION}

Present study is purely observational in nature with objective of generating clinical evidence based on local causes of head injury toward developing rationale for choice and use of neuroprotective therapy. There has been awesome gap in experimental benefits versus clinical success in regard to most agents and this has long hindered translation of scientific development into the clinical practice at large. The observational study using the very scenario of patient care rendered by neurosurgical unit becomes the acceptable means to elucidate and bring home the issue of rationale and thus endeavour to bring desired changes in therapeutics of neuroprotection and rehabilitation.

Funding: No funding sources

Competing interests: None declared

Ethical approval: The study was approved by the Institutional Ethics Committee

\section{REFERENCES}

1. Rink A, Fung KM, Trojanowski JQ, Lee VM, Neugebauer E, McIntosh TK. Evidence of apoptotic cell death after experimental traumatic brain injury in the rat. Am J Pathol 1995;147:1575-83.

2. Faden AI, Salzmen S. Pharmacological strategies in CNS trauma. Trends Pharmacol Sci 1992;13:29-35.

3. Bullock M, Lyeth B, Muizelaar J. Current status of neuroprotection trials for traumatic brain injury: lessons from animal models and clinical studies. Neurosurgery 1999;45:207-17.

4. Krieglstein J, Rischke R. Vinpocetine increases the neuroprotective effect of adenosine in vitro. Eur $\mathbf{J}$ Pharmacol 1991;205:7-10.

5. Rischke R, Krieglstein J. Effects of vinpocetine on local cerebral blood flow and glucose utilization seven days after forebrain ischaemia in the rat. Pharmacology 1990;41:153-60.

6. Jucker M, Meier-Ruge W, Baettig K. Relative regional changes in 2- deoxyglucose uptake reflect cognitive performances in aged and adult rats. Effects of brovincamine and vinpocetine. Psychopharmacology 1988;96:29.

7. Kuzuya F. Effects of vinpocetine on platelet aggregability and erythrocyte deformability. Ther Hung 1958;33:22-34.

8. Szobor A, Klein M. Examinations of the relative fluidity in cerebrovascular disease patients. Ther Hung 1991;40:8-11.

9. Hayakawa M. Effect of vinpocetine on red blood cell deformability in stroke patients. Arzneimittelforschung 1992;42:425-7.

10. Rappaport M, Hall KM et al. Disability Rating Scale for Severe head trauma: Coma to Community. Arch Phys Med Rehabil 1982;63:118-23.

11. Ratcliff JJ, Greenspan AJ, Goldstein FC, et al. Gender and traumatic brain injury: do the sexes face differently? Brain Inj 2007;21:1023-30.

12. Levin $H$. Neurobehavioral outcome of mild to moderate head injury. Boston: Blackwell Scientific, pp 153-85.

13. Kazner E, Sprung C, Adelt D, Ammerer HP, Karnick R, Baumann H, et al. Clinical experience with nimodipine in the prophylaxis of neurological deficits after subarachnoid hemorrhage. Neurochirurgia (Stuttg) 1985;28 Suppl 1:110-3.

14. Mabe H, Takaji $\mathrm{T}$, Umemera $\mathrm{S}$, et al. Effect of Calcium entry blocker Nimodipine on cerebral function and metabolism. No To Shinkei 1985;37:1067-72. 
15. Jakala P, Riekkinen M, Bjorklund $\mathrm{M}$ et al. Efficacy of combined Nimodipine and Metrifonate on rat cognition and cortical Electroencephalograph. Eu J. of Pharmacology 1996;318:239-50.

16. Mourice T, Su TP, Parish DW, Privat A. Prevention of nimodipine-induced impairment of learning by selective sigma ligand PRE-084. J Neural Transm Gen Sect 1995;102:1-18.

17. Wang W, Wang LN, Zhang XH, Ma L, Li DJ. A nimodipine Interventional study of Patients with mild cognitive impairment. Zhonghua Nei Ke Za Zhi 2006;45:274-6.

18. Levy A, Kong RM, Stillman MJ, et al. Nimodipine Improves Spatial Working Memory and Elevates Hippocampal Acetylcholine in Young Rats. Pharmacol Biochem Behav 1991;39:781-6.

19. Bönöczk P, Gulyás B, Adam-Vizi V, et al. Role of sodium channel inhibition in neuroprotection: effect of vinpocetine. Brain Res Bull 2000;53:245-54.

20. Lamar JC, Poignet H, Beaughard M. Calcium antagonist activity of vinpocetine and vincamine in several models of cerebral ischemia. Drug Dev Res 1988;14:297-304. doi: 10.1002/ddr.430140322.

21. Medina AE. Vinpocetine as a potent antiinflammatory agent. Proc Natl Acad Sci U S A. 2010;107:9921-2.
22. Truss MC, Stief CG, Uckert S, et al. Phosphodiesterase 1 inhibition in the treatment of lower urinary tract dysfunction: from bench to bedside. World J Urol 2001;19:344-50.

23. Majumder P, Trujillo CA, Lopes CG, et al. New insights into purinergic receptor signaling in neuronal differentiation, neuroprotection, and brain disorders. Purinergic Signal 2007;3:317-31.

24. Gaál L, Molnár P. Effect of vinpocetine on noradrenergic neurons in rat locus coeruleus. Eur J Pharmacol 1990;187:537-9.

25. Deshmukh R, Sharma V, Mehan S, Sharma N, Bedi KL. Amelioration of intracerebroventricular streptozotocin induced cognitive dysfunction and oxidative stress by vinpocetine — a PDE1 inhibitor. Eur J Pharmacol 2009;620:49-56.

26. Rosdy B, Balazs M, Szporny L. Biochemical effects of ethyl apovincaminate. Arzneimittelforschung 1976;26(10a):1923-6.

27. Trejo F, Nekrassov V, Sitges M. Characterization of vinpocetine effects on DA and DOPAC release in striatal isolated nerve endings. Brain Res 2001;909:59-67.

28. Clark JD, Raggatt PR, Edwards OM. Abnormalities of the hypothalamo-pituitary-gonadal axis after head injury. Clin Endocrinol (Oxf) 1992;36:481-5.

doi: 10.5455/2319-2003.ijbcp20130104

Cite this article as: Singh A, Sharma V, Pandey BL. Comparative effectiveness study of vinpocetine vs. nimodipine on functional recovery in patients of head injury. Int J Basic Clin Pharmacol 2013;2:18-25. 